Malta. R. R.; Costa, N. M. C. Gestão do Uso Público em Unidade de Conservação: a visitação no Parque Nacional da Tijuca - RJ. Revista Brasileira de Ecoturismo, São Paulo, v.2, n.3, 2009, pp.273-

294.

\title{
Gestão do Uso Público em Unidade de Conservação: a Visitação no Parque Nacional da Tijuca $-\mathbf{R J}^{1}$
}

\section{Ricardo Rodrigues Malta, Nadja Maria Castilho da Costa}

\section{RESUMO}

Os apelos ao Ecoturismo e à visitação pública realizada em Unidades de Conservação (UC), tais como os Parques Nacionais, têm crescido de forma significativa nos últimos anos. Entretanto, este aumento da demanda por atividades recreativas e ecoturísticas em áreas naturais também gerou um aumento na degradação socioambiental. Para evitar que isso ocorra, os gestores dessas áreas naturais protegidas deveriam criar ferramentas capazes de manejar a visitação pública de modo a evitar interferências negativas no ambiente visitado. Nesse sentido, o objetivo principal deste trabalho foi caracterizar o perfil e analisar as reações dos visitantes da Floresta da Tijuca, um dos setores mais visitados do Parque Nacional da Tijuca (PNT), localizado na cidade do Rio de Janeiro. O perfil dos visitantes, bem como as características da visitação e suas reações à área natural visitada, são informações fundamentais, na medida em que permitirão à administração do Parque avaliar e promover a criação e/ou melhoria dos atrativos oferecidos, a partir da demanda real do visitante e de suas percepções, satisfações e reações. Após realizarem sua experiência de visitação, os visitantes eram convidados aleatoriamente a participar da pesquisa. Por meio de questionários semiestruturados, os visitantes declaravam informações socioeconômicas e respondiam a questões referentes a sua visitação. Podiam também expressar suas sensações, valores e significados através de perguntas abertas que buscavam avaliar sua percepção ambiental. A amostra considerou apenas visitantes moradores na cidade do Rio de Janeiro. Foram aplicados 228 questionários, entre janeiro e dezembro de 2006, em três pontos na Floresta da Tijuca: largo do Bom Retiro, Cascatinha e Meu Recanto. A maioria dos visitantes da Floresta da Tijuca é constituída pelo sexo masculino $(54,39 \%)$, possui renda familiar mensal maior que dez salários mínimos (31,58\%), faixa etária entre 18 e 35 anos $(65,70 \%)$, nível de escolaridade superior $(61,40 \%)$, e é composta por moradores de bairros vizinhos à área do PNT, tais como: Tijuca, Jacarepaguá, Vila Isabel, Meier e Grajaú. Um percentual de $36,84 \%$ estava visitando a Floresta da Tijuca pela primeira vez, enquanto $46,49 \%$ são considerados frequentadores. A Floresta da Tijuca é muito valorizada como área de lazer para a população carioca, embora ainda seja desconhecida por boa parte da população. Os resultados da pesquisa revelaram um público mais homogêneo, formado por grupos organizados por agências de turismo, escolas, academias, e frequentadores habituais, usuários dos dias de semana que vêm praticar exercícios físicos ou procuram descanso e sossego. Outro público, mais heterogêneo, formado por familiares/amigos, grupos de funcionários de empresas e clubes de caminhada, buscam o PNT nos fins de semana e feriados, visando principalmente a prática de caminhadas. Portanto, é preciso que o gestor do uso público conheça as potencialidades e as limitações de sua UC, bem como o perfil de seus visitantes e suas impressões, evitando, com isso, conflitos de uso e impactos ambientais decorrentes de um processo de visitação insustentável.

PALAVRAS-CHAVE: Ecoturismo, Gestão do Uso Público, Parque Nacional da Tijuca. 


\section{Public Use Management in Conservation Area: the Visitation of Tijuca National Park - RJ - Brazil}

\section{ABSTRACT}

The calls for public visitation and ecotourism in conservation areas (CA), such as National Parks, have grown significantly in recent years. However, this increase in demand for recreation and ecotourism activities in natural areas also generated an increase in socioenvironmental degradation. To avoid this, the managers of these protected natural areas should create tools to manage the public visitation in order to avoid negative interference on the environment visited. Thus, the main objective of this study was to characterize the profile an analyze the reactions of visitors to the Tijuca Forest, one of the most visited sectors of the Tijuca National Park (PNT), located in the city of Rio de Janeiro. The visitors' profile, as well as the characteristics of visitation and their reactions to the natural area visited are key information to the extent that the park's administration will evaluate and promote the creation and / or improvement of the attractions offered, from the actual visitor demand and their perceptions, satisfaction and reactions. After performing their experience of visitation, the visitors were invited to participate of study randomly. Through semi-structured questionnaires, they declared socioeconomic information and answered questions regarding their visitation. They could also express their feelings, values and meanings through open questions that sought to assess their environmental perception. The sample considered only visitors residents in the city of Rio de Janeiro. Between January and December 2006, 228 questionnaires were administered at three points in the Tijuca Forest: largo do Bom Retiro, Cascatinha e Meu Recanto. Most visitors of Tijuca Forest is male (54.39\%), monthly family income has more than ten minimum wages $(31.58 \%)$, aged between 18 and 35 years old $(65.70 \%)$, higher education level $(61.40 \%)$, and resides in the neighboring park, such as Tijuca, Jacarepaguá, Vila Isabel, Meier and Grajaú. A percentage of $36.84 \%$ was visiting the Tijuca Forest for the first time, while another $46.49 \%$ are frequent visitors. The Tijuca Forest is highly valued as a recreational area for carioca population, although it is still unknown by much of these population. The survey results revealed a more homogeneous public of visitors, made up of groups organized by travel agencies, schools, gyms, and frequent visitors, weekdays' users that come to practice physical exercise or seeking rest and quiet. Another group, more heterogeneous, formed by family / friends, work groups and hiking club, look for the PNT on weekends and holidays, mainly targeting the practice of hiking. Therefore, it is necessary that the manager of public use to know the strengths and limitations of their CA and the profile of our visitors and their impressions, avoiding thereby use conflicts and environmental impacts arising from an unsustainable process of visitation

KEY-WORDS: Ecotourism, Management, Public Use Management, the Tijuca National Park. 


\section{INTRODUÇÃO}

Durante séculos de exploração, o homem vem se apoderando dos recursos naturais para satisfazer suas necessidades de consumo, seja através do uso direto, quanto indireto, como por exemplo, a visitação de ambientes naturais para a realização de atividades recreativas e ecoturísticas.

Desde a década de 1980, há um apelo considerável para as viagens em que os aspectos naturais e paisagísticos constituem-se no principal atrativo, onde os visitantes têm a oportunidade de conhecer e apreciar a natureza. Assim, atualmente, observa-se uma tendência: os principais destinos ecoturísticos têm sido as Unidades de Conservação (UC's). A Organização Mundial do Turismo (OMT) estima que 10\% das pessoas que viajam pelo mundo são ecoturistas. No Brasil, pressupõe-se que o Ecoturismo alcance $\mathbf{5 0 0}$ mil turistas por ano. Dentre as áreas naturais protegidas, os Parques Nacionais, Estaduais e Municipais, as Florestas Nacionais, e as Áreas de Proteção Ambiental (APA's) são as escolhidas como locais para que se opere o Ecoturismo, tanto no âmbito nacional, como no internacional.

Segundo Barros e Dines (2000), o aumento do número de visitantes que procuram as poucas áreas naturais remanescentes ocorre em função de um conjunto complexo de novas condições: a) organização do setor formal do turismo; b) maiores facilidades de acesso; c) crescente disponibilidade e qualidade de equipamentos; d) divulgação maciça dessas áreas e atividades pelos meios de comunicação; e, principalmente, e) as oportunidades para a prática de atividades recreativas e turísticas em áreas naturais protegidas, principalmente em parques.

Nesse sentido, uma das justificativas para a criação das UC's, cuja categoria prevê a visitação e o uso público é possibilitar o contato de pessoas com a natureza, principalmente, por meio de atividades recreativas e ecoturísticas.

A recreação e o Ecoturismo podem usar os recursos naturais de forma indireta. $\mathrm{O}$ ambiente natural pode ser apreciado e contemplado, por meio de experiências e vivências interativas. Dessa forma, essas atividades ofereceriam uma afinidade incontestável com as UC's, particularmente os parques nacionais.

O Parque Nacional da Tijuca (PNT), onde está inserida a Floresta da Tijuca, objeto do presente estudo, pertence à categoria das "Unidades de Proteção Integral" do Sistema Nacional de Unidades de Conservação da Natureza $\left(S_{N} \mathrm{CC}^{2}\right)$, cujo objetivo básico é "preservar a natureza, sendo admitido apenas o uso indireto dos seus recursos naturais" ${ }^{3}$, neste caso, o processo de lazer e recreação controlados.

A escolha da Floresta da Tijuca como objeto de estudo, justificou-se tendo em vista ser: a) um importante remanescente de Mata Atlântica, um dos biomas mais ameaçados de extinção no mundo; b) uma importante área de recreação e Ecoturismo para os moradores da cidade do Rio de Janeiro, pois concentra a maior parte do patrimônio histórico-cultural do PNT, diversos locais para piquenique, recreação, lazer, Ecoturismo, descanso e contemplação; e c) uma área de relevância ecológica internacional, em se tratando de uma experiência pioneira em silvicultura tropical (BUENO, 1998). 
O objetivo do presente trabalho é destacar o perfil e as reações dos visitantes da Floresta da Tijuca, bem como as características da visitação, visando subsidiar o uso público na mais importante área protegida da cidade do Rio de Janeiro. Estes aspectos constituem-se num importante instrumento de gestão, uma vez que fornecem informações que ajudam no delineamento de uma política de uso público da área natural protegida que contemple não somente os objetivos da unidade, mas também fatores que valorizam a experiência do visitante no local.

\section{Área de estudo}

O PNT está inserido no maciço da Tijuca, localizado na cidade do Rio de Janeiro, entre os paralelos $22^{\circ} 55^{\prime} \mathrm{S}$ e $2^{\circ} 00^{\prime} \mathrm{S}$ e os meridianos $43^{\circ} 11^{\prime} \mathrm{W}$ e $43^{\circ} 19^{\prime} \mathrm{W}$. Estende-se por uma área de $39,53 \mathrm{~km}^{2}$, circundada por alguns dos principais bairros residenciais da cidade (Figura 1), entre eles: Tijuca, Barra da Tijuca, Freguesia, Grajaú, São Conrado, Jardim Botânico e Gávea. É constituído por quatro setores, diferenciados: pelo uso e ocupação, pelas características ambientais e pelo estado de conservação. São eles: (A) Floresta da Tijuca - área de 14,73 km²; (B) Parque Lage e Complexo da Carioca $\left(17,28 \mathrm{~km}^{2}\right)$; (C) Pedra da Gávea e Pedra Bonita $\left(2,5 \mathrm{~km}^{2}\right)$; e (D) Floresta da Covanca e Serra dos Pretos Forros $\left(5 \mathrm{~km}^{2}\right)$.

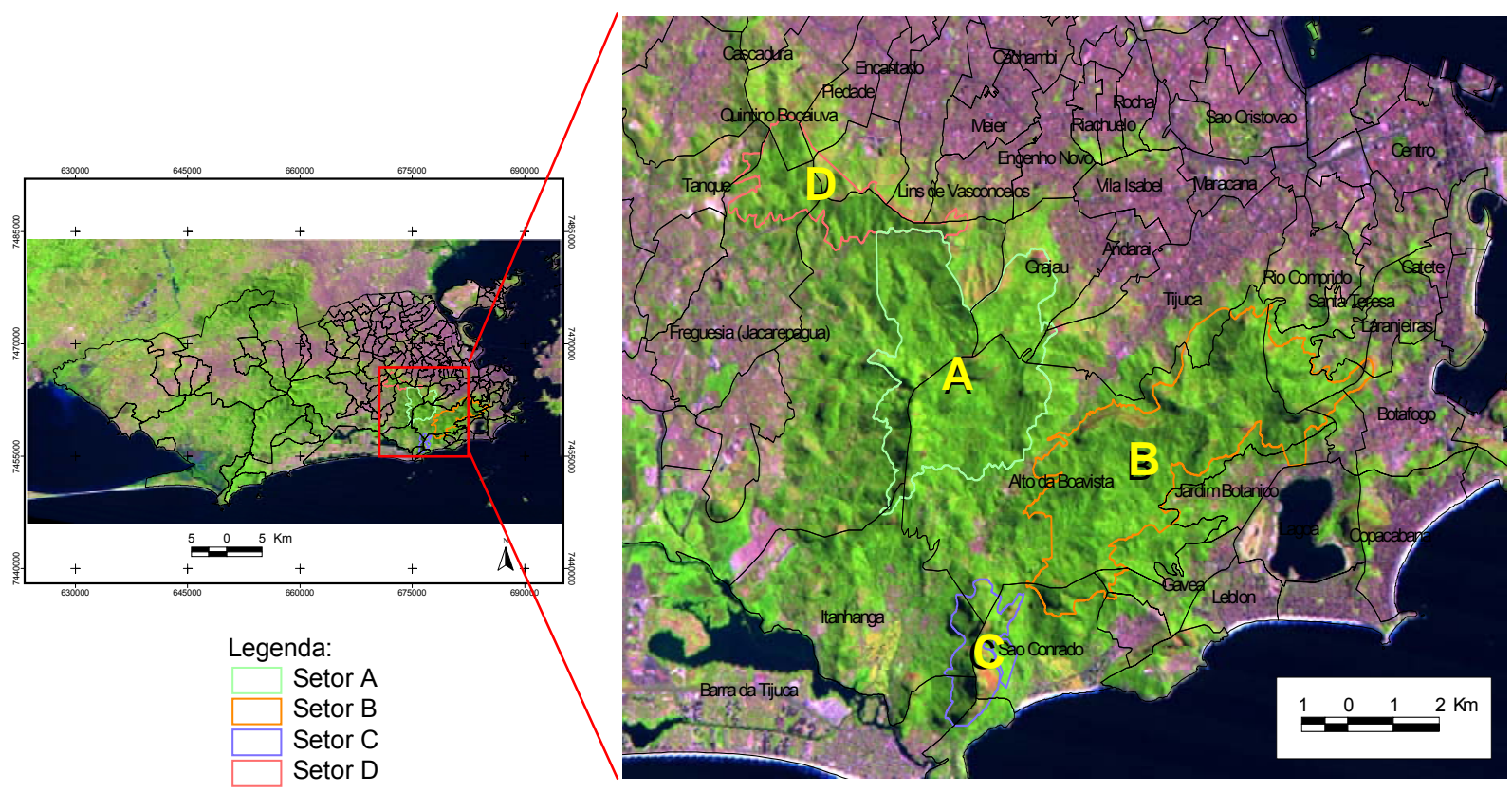

Figura 1 - Mapa de Localização do Parque Nacional da Tijuca (PNT).

Fonte: Imagem de satélite Landsat 7 (1998) com divisão de bairros do município do Rio de Janeiro e limites do PNT (IPP/DIG, 2005). Realizado no Arcview 3.2 (ESRI) por Ricardo Malta e Vivian Costa, 2008. 
Utilizando as bases digitais do Instituto Municipal de Urbanismo Pereira Passos (IPP), foi traçada uma zona de amortecimento (buffer) de $1 \mathrm{~km}$ ao redor dos limites territoriais do PNT. O mapa revelou que trinta favelas estão localizadas, parcial ou integralmente, nessa área, e que outras cinquenta estão localizadas em áreas limítrofes a esta (Figura 2).
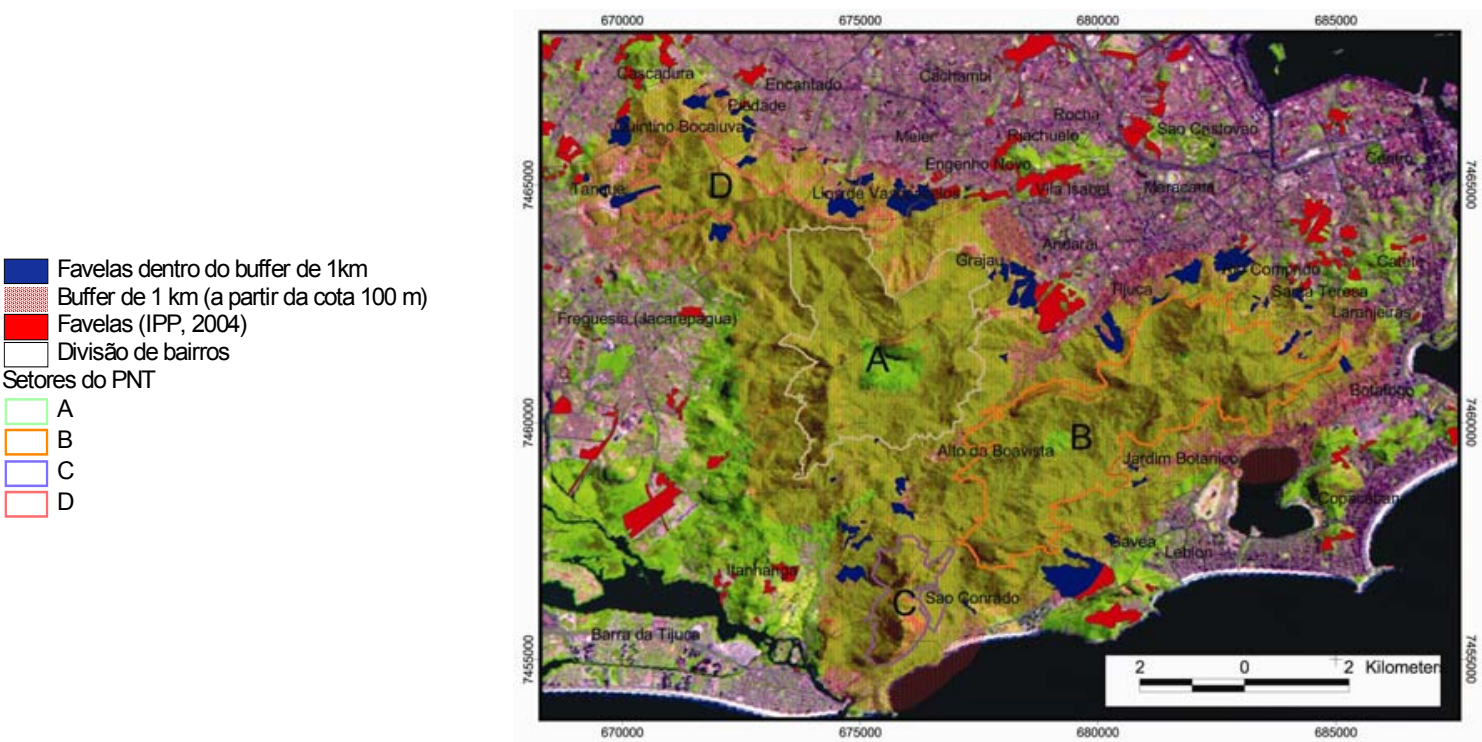

Figura 2 - Zona de Amortecimento do Parque Nacional da Tijuca (PNT). Carta-Imagem com ocupações humanas sub-normais (favelas ${ }^{4}$ ) na faixa (buffer) de $1 \mathrm{~km}$ do Parque Nacional da Tijuca (Zona de Amortecimento). Fonte: Imagem de satélite Landsat 7 (1998), Mapa de fave-

las do município do Rio de Janeiro (IPP/DIG, 2004). Realizado no Arcview 3.2 (ESRI) por Ricardo Malta e Vivian Costa, 2008.

A ocupação humana que ocorreu nas áreas do maciço da Tijuca e, consequentemente, no território do PNT, apesar da proibição da urbanização de áreas acima da cota de 100 metros pela Lei de Zoneamento Municipal, que consta do Decreto $n^{\circ} 322$ de 1976, continua ocorrendo de forma acelerada, trazendo graves transtornos ao Parque. Além disso, o desmatamento das encostas causa frequentes deslizamentos e acidentes, gerando grande prejuízo social e econômico à cidade.

\section{Breve história ambiental e processo de criação do PNT}

Com relação ao processo de criação do PNT, é importante fazer uma breve descrição da história ambiental da região. A fundação da cidade do Rio de Janeiro, em 1565, foi determinante para iniciar-se o processo de desmatamento das florestas do Maciço da Tijuca ${ }^{5}$. A construção civil e a utilização de lenha no consumo doméstico aumentavam gradualmente a demanda por madeira. Outro fator agravante do desmatamento foi a expansão do ciclo da cana-de-açúcar, em meados do século XVII. As 
florestas das encostas mais baixas e menos íngremes do maciço foram dando lugar à cana através da técnica de queimadas. Contudo, o cenário piorou no final do século XVIII, com as plantações de café (ISER, PNT, 1999; IBDF, FBCN, 1981; DRUMMOND, 1997).

Com a chegada da Família Real Portuguesa, em 1808, houve um incremento considerável da população de residentes. Como consequência, intensificaram-se o plantio de café e de espécies exóticas, e a exploração de madeira para a construção de casas (ISER, PNT, 1999; IBDF, FBCN, 1981). Porém, os cortes e as queimadas destruíram extensas áreas de floresta, comprometendo os mananciais de água, fazendo a cidade sofrer crises de abastecimento de água (IBDF, FBCN, 1981).

Com a crise da falta de água, teve início, em 1817, o processo de recuperação das florestas do Maciço da Tijuca, através de uma série de decretos baixados por $D$. João $\mathrm{VI}$, visando preservar os mananciais da região, através do fim do corte de árvores junto a mananciais e margens de rios, e da desapropriação de terras de particulares. Não havia, entretanto, uma preocupação com a natureza nessas medidas. Como a situação agravou-se, foi necessário um programa de reflorestamento nas florestas da Tijuca e das Paineiras (DRUMMOND, 1997; IBDF, 1982). Iniciado em 1862 pelo Major Archer, o plantio priorizou as espécies nativas da Mata Atlântica. Porém, seu sucessor, o Barão d'Escragnolle, optou, em maior escala, por espécies exóticas. Escragnolle viu na Floresta da Tijuca a vocação de grande parque urbano, transformando-a em lugar cheio de recantos aprazíveis à visitação pública. Para isso, contou com o auxílio do paisagista francês Auguste Glaziou, para modelar jardins em estilo francês, construindo pontes, praças, lagos e chafarizes, que transformaram a Floresta da Tijuca num dos mais atraentes lugares do Rio de Janeiro (IBDF, FBCN, 1981; FRANCO, 2001). Assim, na segunda metade do século XIX, a fama da Floresta da Tijuca, como um dos mais agradáveis recantos da cidade, ficou notória.

Contudo, com a transição do Império para a República, a preservação florestal passou para segundo plano, resultando num estado de abandono de cinquenta anos, onde a Floresta se regeneraria por conta própria, sem interferência humana. A definitiva transformação da Floresta da Tijuca em área de lazer e de turismo só aconteceria em 1945, na administração de Raymundo de Castro Maya (IBDF, FBCN, 1981).

Criado, em 1961, com o nome de Parque Nacional do Rio de Janeiro, o parque incorporou as florestas de domínio da União existentes na área do Maciço da Tijuca tais como Tijuca e Paineiras. Em 1967, o parque passou a se chamar Parque Nacional da Tijuca, estabelecendo novas dimensões e características. Recentemente, em 2004, outras áreas - como, por exemplo, o Parque Lage - foram anexadas ao parque.

\section{Infraestrutura de lazer}

Integram a área da Floresta da Tijuca, uma das maiores florestas em área urbana no mundo, belezas paisagísticas e cênicas, atrativos naturais e históricoculturais, além de infraestrutura de equipamentos de lazer, instalações e serviços essenciais para o desenvolvimento de atividades esportivas, educativas, recreativas e 
ecoturísticas. Os visitantes buscam as inúmeras possibilidades de recreação, lazer, educação e Ecoturismo que a Floresta da Tijuca oferece, pois existem muitos locais para a realização de várias atividades, tais como: piqueniques, churrascos, recreação infantil, meditação, passeios, caminhadas, andar de bicicleta, observação da paisagem, observação da fauna, rapel (Figura 3), escaladas, visitação de sítios e monumentos históricos e arqueológicos, descanso e contemplação da natureza.

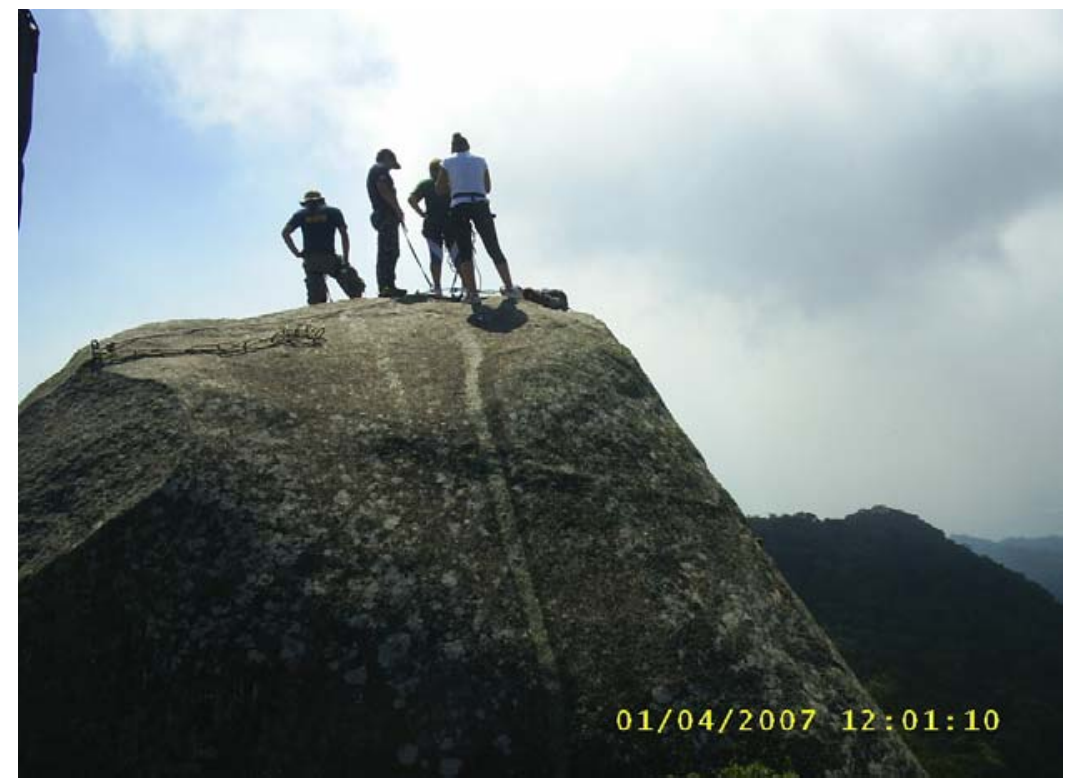

Figura 3 - Prática de rapel no Pico do Bico do Papagaio. Foto de Ricardo Malta, em $1^{\circ}$ de abril de 2007.

As diversas trilhas e caminhos históricos podem levar os visitantes a atrativos histórico-culturais, naturais e paisagísticos. A maior parte das trilhas data do século $\mathrm{XIX}$, quando foram realizados os trabalhos de reflorestamento pelo Major Archer, sendo algumas utilizadas com frequência, à época, por membros da Corte. De acordo com Bandeira (1993) e Cunha e Menezes (1996; 1998), as trilhas foram refuncionalizadas para a prática do turismo em áreas naturais. O pico do Bico do Papagaio (990 metros de altitude), o pico da Tijuca $(1.021 \mathrm{~m})$ e a pedra do Conde $(819 \mathrm{~m})$ são muito procurados por montanhistas e alpinistas. De seus topos, é possível ter ampla vista panorâmica da cidade do Rio de Janeiro, da baixada de Jacarepaguá e suas lagoas, da serra do Mar, da baía de Guanabara e dos maciços da Pedra Branca e do Gericinó-Mendanha.

A área da Floresta da Tijuca conta com recursos naturais variados, tais como: grutas, quedas d'água (cascatas e cachoeiras), lagos, açudes e mirantes. Entre eles destacam-se: a gruta Paulo e Virginia, a vista do Almirante (608 m), o açude da Solidão, a cascatinha de Taunay, o lago das Fadas e a área de lazer do largo do Bom Retiro. São também significativas a represa dos Ciganos, localizada na Floresta Santa Inês, e as ruínas de Vila Rica, importante sítio histórico localizado na Floresta do An- 
daraí.

Com relação à infraestrutura de instalações, equipamentos e serviços que a Floresta da Tijuca dispõe, pode-se encontrar:

- $\quad$ áreas de lazer para piqueniques (Figura 4) com churrasqueiras, bancos e mesas, bebedouros e cestas coletoras de lixo, localizadas nos largos da Cascatinha, do Mayrink e do Bom Retiro, no Meu Recanto, no recanto das Jaboticabeiras - em frente ao Barracão (administração do PNT) -, no lago das Fadas, no setor das Grutas (área Paulo e Virgínia), e no açude da Solidão;

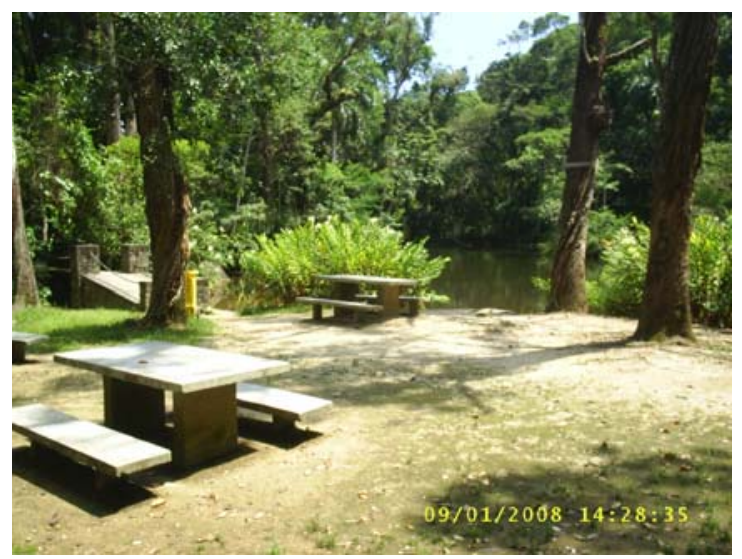

Figura 4 - Área de lazer do açude da Solidão. Foto: Ricardo Malta, em 9 de janeiro de 2008.

- área para prática de tai-chi chuan, entre outras práticas de artes marciais ou de meditação - local conhecido como recanto do Tai-Chi, próximo ao Barracão;

- uma loja de souvenires, situada no largo da Cascatinha;

- três restaurantes: "Cascatinha", "A Floresta" e "Os Esquilos";

- sanitários públicos, localizados nos largos da Cascatinha, do Mayrink e do Bom Retiro, no Centro de Visitantes, na área Paulo e Virgínia e no açude da Solidão;

- três orelhões de uso público, localizados no largo do Bom Retiro, no Barracão e no Centro de Visitantes;

- rampas para deficientes físicos, no Centro de Visitantes;

- estacionamentos, localizados nos largos da Cascatinha, do Mayrink e do Bom Retiro, no Meu Recanto, no setor das Grutas, no açude da Solidão, e nos restaurantes Os Esquilos e A Floresta;

- pátios - playgrounds - com brinquedos para recreação infantil (Figura 5), localizados nos largos do Mayrink e do Bom Retiro; 
Malta, R. R.; Costa, N. M. C.

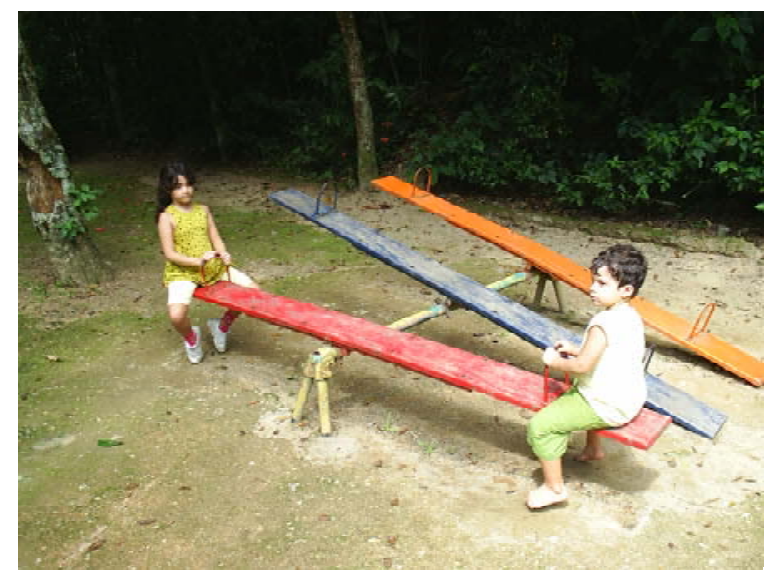

Figura 5 - Brinquedos para recreação infantil, na área de lazer do largo do Bom Retiro. Foto de Ricardo Malta, em 10 de abril de 2005.

- sinalização bilíngue, indicativa e interpretativa (Figura 6) - placas localizadas no portão da Floresta, ao longo das trilhas dos Estudantes e dos Bancos, nos largos da Cascatinha, do Mayrink e do Bom Retiro, no Centro de Visitantes, no sítio do Midosi, no Meu Recanto, no setor das Grutas, no açude da Solidão, e na entrada de algumas trilhas, como a da Cova da Onça e a do pico da Tijuca;

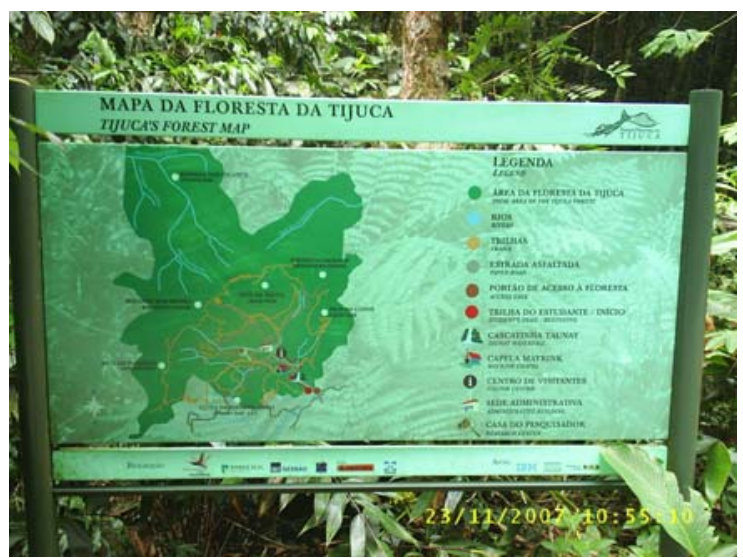

Figura 6 - Sinalização bilíngue, na entrada da trilha dos Estudantes, na estrada da Cascatinha. Foto de Ricardo Malta, em 23 de novembro de 2007.

- placas sinalizadoras dos atrativos, localizadas ao longo das trilhas;

- trilhas, caminhos históricos e estradas;

- ciclovia, ao longo das estradas pavimentadas da Floresta da Tijuca.

Na Floresta da Tijuca destacam-se, ainda, recantos históricos e objetos turísticos de cunho histórico-cultural, partes componentes do sistema de visitação da Floresta da Tijuca. 


\section{Uso público e visitação}

Uma das justificativas para criação de UC's cuja categoria prevê a visitação e o uso público é possibilitar o contato de pessoas com a natureza, através de práticas recreativas e ecoturísticas, principalmente.

O Instituto Brasileiro do Meio Ambiente e dos Recursos Naturais Renováveis (IBAMA) conceitua "uso público" ou "visitação" como as atividades educativas, recreativas e de interpretação ambiental realizadas em contato com a natureza de acordo com o especificado nos planos de manejo das UC's. Seu principal objetivo é propiciar ao visitante a oportunidade de conhecer, de forma lúdica, os atributos e os valores ambientais protegidos pela UC.

Segundo Hendee et al. (apud BARROS, 2003), o conceito de uso público abrange diversos tipos de uso, entre os quais: recreativo; comercial; científico; educacional; de desenvolvimento pessoal.

$\mathrm{O}$ uso de UC's com propósitos recreativos teve suas primeiras iniciativas no século XVI, sendo 'concretizadas' em 1872, com a criação do Yellowstone National Park. Um dos principais argumentos para a criação deste parque foi o apelo para o desenvolvimento de atividades recreativas.

Atualmente, observa-se uma tendência: os principais destinos turísticos têm sido as UC's. Desde a década de 1980, há um apelo considerável para as viagens em que os aspectos naturais constituem-se no principal atrativo, em que os visitantes têm a oportunidade de conhecer e apreciar a natureza.

Segundo Barros e Dines (2000), o aumento do número de visitantes que procuram as poucas áreas naturais remanescentes ocorre em função de um conjunto complexo de novas condições: a) organização do setor formal do turismo; b) maiores facilidades de acesso; c) crescente disponibilidade e qualidade de equipamentos; d) divulgação maciça dessas áreas e atividades pelos meios de comunicação; e, principalmente, e) as oportunidades para a prática de atividades recreativas e turísticas em áreas naturais protegidas, principalmente em parques.

A visitação em UC's, entretanto, possui vantagens (Quadro 1), e desvantagens.

Os impactos negativos referem-se à degradação do meio ambiente, às mudanças socioculturais (interferências no cotidiano das populações locais) e à não-inclusão das comunidades do entorno nas discussões de gestão do uso e na formação de renda. O PNT, por exemplo, recebe, aproximadamente, 1.450 .000 visitantes/ano que desenvolvem suas experiências recreativas sem que haja um monitoramento contínuo dos efeitos de suas atividades no ecossistema. A pressão da "sobrevisitação" acarreta inúmeros danos às condições ecológicas e recreativas das UC's.

Segundo Freixêdas-Vieira et al. (2000), de uma forma geral, as áreas de uso público das UC's brasileiras, cujos planos de manejo não foram atualizados, foram planejadas para atender uma demanda menor do que a atual, com atividades menos impactantes e com um público muito diferente do atual. "Uma visita mal orientada e planejada pode gerar conflitos e tensões entre os próprios usuários, diminuindo a qualidade da experiência da visita", ressalta Niefer (2002, p.19). A superlotação afeta o nível de satisfação dos visitantes. 
Malta, R. R.; Costa, N. M. C.

Quadro 1 - Benefícios potenciais da visitação em Unidades de Conservação

\begin{tabular}{|c|c|}
\hline Vantagens & \begin{tabular}{|c|} 
Benefícios \\
\end{tabular} \\
\hline $\begin{array}{c}\text { Aumento de opor- } \\
\text { tunidades econô- } \\
\text { micas }\end{array}$ & $\begin{array}{l}\text { - estimula novas empresas e diversifica a economia local; } \\
\text { - aumenta a oferta de empregos para a comunidade; } \\
\text { - aumenta a renda; } \\
\text { - estimula a manufatura de bens locais; } \\
\text { - melhora o padrão de vida; } \\
\text { - capacita os funcionários às novas atividades; } \\
\text { - aumenta o fundo para a proteção da unidade e comunidade local. }\end{array}$ \\
\hline $\begin{array}{c}\text { Proteção do patri- } \\
\text { mônio natural e } \\
\text { cultural }\end{array}$ & $\begin{array}{l}\text { - protege os processos ecológicos; } \\
\text { - conserva a biodiversidade; } \\
\text { - melhora as facilidades de transporte e comunicação; } \\
\text { - auxilia a desenvolver mecanismos de financiamento para as unidades; } \\
\text { - cria valores econômicos e protege recursos que não seriam percebidos pe- } \\
\text { la comunidade local de outra forma; } \\
\text { - transmite valores de conservação por meio da educação e interpretação; } \\
\text { - apoia as pesquisas e desenvolvimento de um sistema de manejo. }\end{array}$ \\
\hline $\begin{array}{l}\text { Melhoria da quali- } \\
\text { dade de vida }\end{array}$ & $\begin{array}{l}\text { - promove os valores estéticos, espirituais e de bem-estar; } \\
\text { - apoia a educação ambiental para visitantes e comunidade local } \\
\text { - estimula o desenvolvimento da cultura, artes e artesanato; } \\
\text { - aumenta o nível educacional da comunidade local; } \\
\text { - estimula a comunidade a valorizar sua cultura e ambiente regional; } \\
\text { - estimula as pessoas a aprenderem as línguas e culturas dos turistas es- } \\
\text { trangeiros. }\end{array}$ \\
\hline
\end{tabular}

Fonte: Takahashi (2004), adaptado por Ricardo Malta. do público.

Visando manejar os visitantes e seus impactos são realizadas segmentações

Procurando enquadrar melhor os consumidores de Ecoturismo, Meirelles Filho (2005) propôs algumas bases de segmentação:

- a segmentação geográfica objetiva organizar a demanda a partir de divisões como local de origem (procedência) e destino, permitindo o conhecimento dos fluxos turísticos. São parâmetros objetivos que irão colaborar na definição da segmentação psicográfica e comportamental, permitindo estabelecer padrões de atitude para os diferentes grupos de visitantes;

- a segmentação comportamental diz respeito aos hábitos do público, aos costumes de determinado grupo ou família que visita uma área natural. As reações que um público essencialmente urbano tem ao se defrontar com uma área natural precisam ser monitoradas para que se conheça o grau de satisfação ou insatisfação que provoca; e

- a segmentação psicográfica objetiva conhecer melhor as motivações dos visitantes, baseando-se em sua personalidade. As reações dos visitantes diante de determinadas situações positivas ou negativas. A psicografia tenta determinar suas motivações, interesses em atividades, preferências, atitudes, valores, opiniões e estilos de vida (HEATH, 1995; WEINSTEIN, 1995; BLAMEY, BRAITHWAITE, 1997; LAGE, MILONE, 2000 - todos apud NIEFER, 2002).

Corroborando com Pearce e Moscardo (1984), o estudo das queixas e experi- 
ências negativas dos visitantes também poderia ser um método apropriado para avaliar o visitante, pois suas reações refletiriam suas percepções cognitivas, satisfações e sentimentos em relação à área natural visitada. Os autores afirmam que os visitantes ficariam mais satisfeitos ainda com suas experiências se interagissem atentamente com o meio ambiente (PEARCE, MOSCARDO, 1985).

Morley (1990) argumenta que a demanda por lazer ou visitas a espaços naturais é uma função de características do visitante individual, como renda, idade, motivações e constituição psicológica, que afetam de diversas maneiras sua propensão de viajar por prazer, sua capacidade de viajar e sua escolha do destino das viagens. Diz também que a demanda é uma função de características e atributos dos destinos das viagens, seus atrativos, preços e a eficácia do marketing relativo ao destino. $O$ autor acredita que os fatores sociais também podem ter influência sobre a demanda por meio da atitude dos habitantes locais em relação aos visitantes e ao interesse gerado pela cultura local, por exemplo.

Segundo Mannell e Iso-Ahola (1987), duas forças motivacionais influenciam simultaneamente o lazer do indivíduo e o comportamento do visitante: sair da rotina e de ambientes estressantes, e procurar oportunidades recreacionais em busca de certas satisfações intrínsecas. A dimensão de fuga é, portanto, segundo os autores, uma força motivacional mais importante do que a dimensão de busca para o turismo e o lazer.

Os apelos ao Ecoturismo e à visitação pública em UC's, como os parques nacionais, têm crescido de forma significativa nos últimos anos. Entretanto, este aumento da demanda por atividades recreativas e ecoturísticas em áreas naturais protegidas também gerou um aumento na degradação socioambiental - interferências físicas, bióticas e antrópicas -, devido à ausência de instrumentos de gestão do uso público nessas unidades. O aumento da pressão nos recursos naturais utilizados "tem demandado pesquisas dirigidas acerca do fenômeno turístico e da visitação em áreas naturais protegidas, que embasem ações coerentes de manejo, de modo que a atividade exiba seu potencial benéfico em detrimento dos seus riscos" (KINKER, 2002, p.109).

Aproveitando-se da clássica modelagem dos núcleos receptores europeus de Eugene (1980), inicialmente, a atividade ecoturística revela e valoriza os atrativos e recursos naturais, baseados no núcleo receptor, no caso a UC. Posteriormente, o aumento no fluxo ecoturístico de forma não controlada passa a caracterizar um tipo de turismo na natureza com características semelhantes ao turismo de massa, que altera as condições originais do núcleo, gerando degradação do meio ambiente natural e artificial, neste caso as infraestruturas utilizadas pelos usuários em suas atividades de lazer, recreação e Ecoturismo, ou seja, o Ecoturismo "descontrolado" destrói o Ecoturismo "idealizado" na unidade. A terceira fase é a da reparação, surgindo a necessidade de regulamentos, legislações, obras de reposição e recuperação do ambiente degradado pelo uso insustentável. Na última fase temos a reconciliação, onde pesquisas, projetos e estudos tentarão se antecipar às ameaças e desafios futuros, tentando evitar a repetição dos erros cometidos no passado. Alguns estudos foram realizados em Parques Nacionais brasileiros visando conhecer o comportamento de seus visitan- 
tes e contribuir para a criação de um Programa de Uso Público nessas unidades (NIEFER, 2002; BARROS, 2003; CASTRO, 2005; SILVA et al., 2005; TAKAHASHI, 1998). Nesse sentido, para evitar esses erros, os gestores dessas áreas devem criar ferramentas capazes de manejar a visitação pública, a fim de atingir os objetivos do plano de manejo da UC.

Assim, os Programas de Uso Público têm por objetivo propiciar lazer, recreação e educação ambiental à comunidade, bem como despertar uma consciência crítica para a necessidade de conservação dos recursos naturais das UC's, além de esclarecer o público em geral, sobre as responsabilidades, as dimensões e a importância dessas áreas na conservação da biodiversidade (MMA; IBAMA, 1997 apud FREITAS et al., 2002).

\section{METODOLOGIA}

Inicialmente foi realizado o levantamento de dados e informações através da pesquisa bibliográfica e na internet, o que fundamentou as pesquisas de gabinete e de campo. Dados secundários foram levantados junto aos órgãos públicos e instituições acadêmicas: bases digitais cartográficas na Fundação Centro de Informações e Dados do Rio de Janeiro (Fundação CIDE) e no Instituto Municipal de Urbanismo Pereira Passos (IPP); informações do Plano de Manejo do PNT (IBDF, FBCN, 1981); dados quantitativos sobre a visitação da Floresta da Tijuca no Setor de Ecoturismo do PNT; acervos bibliográficos da Universidade Federal do Rio de Janeiro (UFRJ), da Universidade do Estado do Rio de Janeiro (UERJ) e da biblioteca do PNT.

Foi utilizado o software Arcview 3.2 para a entrada das bases cartográficas e geração do mapa de localização da área de estudo. Através das ferramentas de extensão do software Arcview 3.2 chamadas XTools e Buffer selected features foi criado o buffer de $1 \mathrm{~km}$ a partir da cota 100 metros dos setores do PNT, visando espacializar as favelas localizadas no seu entorno imediato, considerando o fato do Parque estar localizado numa área urbana.

Tomando como base alguns estudos (ISER, 2000; COSTA, 2002; KINKER, 2002; SANT'ANNA, 2005; SILVA et al., 2005) foi elaborado um questionário semiestruturado, visando caracterizar o perfil dos visitantes e as características da visitação, através de informações que descrevessem os aspectos mais relevantes, tais como: a experiência anterior; a frequência de visitação; o tamanho do grupo; a forma de viajar; as atividades desenvolvidas pelos visitantes; a duração da visita, ou seja, o tempo de permanência no local; os motivos da visita; os meios de transporte utilizados; sua origem; as preferências; se costuma visitar outras áreas naturais nas quais poderia aproveitar o seu tempo livre em atividades de recreação; seus dados socioeconômicos, como nível de escolaridade, renda mensal familiar, faixa etária e gênero.

Os dados foram coletados in loco onde os visitantes, ao término de uma caminhada ou trilha, ou ao se prepararem para ir embora nos estacionamentos do Parque, eram abordados e convidados a participar da pesquisa, respondendo aos questionários escritos. Por comodidade do entrevistado, poderia ser também realizada a entre- 
vista anotada. A técnica de investigação por inquérito inclui tanto o questionário escrito quanto a entrevista oral, anotada, gravada ou videogravada. Foram escolhidos finais de semana e feriados para aplicação dos questionários, por se tratarem de dias com maior contingente de visitantes, bem como dois dias de semana aleatórios, visando abordar também na amostra o público frequentador habitual do Parque.

Os questionários foram aplicados no período de janeiro a dezembro de 2006. Os locais escolhidos para sua aplicação foram o Meu Recanto, a Cascatinha, e o largo do Bom Retiro, por se tratarem de locais com grande fluxo de visitantes.

O público-alvo da pesquisa foi o visitante da Floresta da Tijuca, morador da cidade do Rio de Janeiro, com idade superior a 18 anos. O tipo de amostra utilizada foi a "não probabilística por conveniência", onde o entrevistado era selecionado por estar disponível no local e no momento em que a pesquisa era realizada (MATTAR, 1994).

Os dados referentes ao número de visitantes que a Floresta da Tijuca recebeu, de janeiro de 2004 a outubro de 2007, foram obtidos junto ao setor de Ecoturismo do PNT, localizado no Centro de Visitantes da Floresta da Tijuca. Como os valores são muito altos, na ordem de 340 mil visitantes anuais, a amostragem de 228 questionários foi considerada satisfatória, na medida em que as principais perguntas fechadas e abertas foram se tornando recorrentes. Após a realização da primeira campanha de campo, alguns questionários foram descartados da amostra em virtude de falhas no preenchimento por parte dos visitantes. Os questionários passaram, então, a ser preenchidos perante a supervisão do próprio pesquisador, visando evitar a continuidade dos erros amostrais.

Os dados primários coletados em campanhas de campo foram tabulados e analisados estatisticamente através do software Excel for Windows.

\section{PRINCIPAIS RESULTADOS}

Através da pesquisa de campo foi possível caracterizar dois tipos de usuários da Floresta da Tijuca: um público "mais homogêneo", usuários dos dias de semana, quando a área natural é frequentada por grupos organizados por agências de turismo, escolas e academias, além de frequentadores habituais que vêm praticar exercícios físicos ou vêm em busca de descanso, relaxamento e sossego; outro público, mais heterogêneo, formado por familiares/amigos, grupos de funcionários de empresas e clubes de caminhada, que buscam o parque durante os finais de semana e feriados como área de: lazer para prática de caminhadas, piqueniques em família, prática de esportes de aventura, treinamentos ao ar livre, contemplação e descanso. Esse último grupo, geralmente utiliza o automóvel como meio de transporte, o que acaba gerando impactos negativos na experiência de visitação e no ambiente visitado.

A maioria dos visitantes da Floresta da Tijuca é constituída pelo sexo masculino $(54,39 \%)$ e suas atividades profissionais são bastante diversificadas, ocorrendo, porém, predomínio de algumas delas: profissionais liberais $(38,16 \%)$; estudantes de diferentes níveis (12,72\%); e professores (9,21\%).

Com relação à renda familiar mensal dos visitantes entrevistados, 31,58\% recebem mais de dez salários mínimos e 35,97\% ganham até quatro salários mínimos, o 
que demonstra a importância que a Floresta da Tijuca exerce como área de lazer gratuita e de fácil acesso para diferentes classes sociais, um espaço socionatural democrático. Nos parques nacionais estudados por Kinker (2002), entretanto, a maioria dos visitantes tem nível superior e renda mensal entre $R \$ 500,00$ e $R \$ 3.000,00$, o que indica que não se trata de um turismo popular.

A faixa etária dos entrevistados é constituída, predominantemente, por indivíduos jovens: $65,70 \%$ dos visitantes apresentam idades entre 18 e 35 anos.

A maioria dos visitantes apresenta nível de escolaridade superior $(61,40 \%)$, seguido de indivíduos com o ensino médio $(29,82 \%)$ e de visitantes que têm nível de escolaridade baixo, ou não concluíram o ensino fundamental $(5,26 \%)$. O nível cultural dos indivíduos deve ser um elemento balizador nos programas de Educação e Interpretação Ambiental em UC's.

Considerando que a amostra pesquisada era composta por visitantes residentes na cidade do Rio de Janeiro, a maioria desses visitantes era proveniente de bairros localizados no entorno dos limites territoriais do Parque, tais como: Tijuca, Jacarepaguá, Vila Isabel, Méier, Grajaú, Freguesia de Jacarepaguá, Laranjeiras e Barra da Tijuca. Os entrevistados procedentes desses bairros - limítrofes ao PNT - perfizeram um total de $42,98 \%$ dos visitantes. Kinker (2002) faz uma análise comparativa de três parques nacionais brasileiros - Aparados da Serra (RS/SC), Serra Geral (RS/SC) e Caparaó (MG/ES) - quanto ao manejo da visitação: em geral, a maioria dos visitantes vem dos Estados onde os parques estão localizados, caracterizando um turismo regional.

A Floresta da Tijuca apresenta uma considerável diversidade de grupos de visitantes, sendo que a maioria deles vem acompanhada de amigos $(42,11 \%)$ e de familiares $(24,12 \%)$.

Com relação ao número de pessoas que compõem os grupos de visitantes, $70,13 \%$ desses grupos são compostos de dois a quatro visitantes. Esses dados são de muito relevantes para a implantação de um Programa de Uso Público, pois é imprescindível que a gestão do Parque direcione atividades recreativas para cada grupo específico, passando a oferecer produtos e serviços segmentados.

Um número representativo de entrevistados, 36,84\%, estava visitando a Floresta da Tijuca pela primeira vez, o que demonstra o seu grande potencial como área de lazer ainda inexplorado pela população carioca, particularmente.

Com relação aos visitantes "eventuais", quer dizer, que estavam visitando a Floresta pela segunda vez ou aqueles que a visitam até três vezes ao ano, eles representaram $16,66 \%$ da amostra. Os indivíduos desses grupos são "visitantes".

Por outro lado, $46,49 \%$ dos indivíduos que foram abordados são "frequentadores", ou seja, utilizam o parque durante seu cotidiano com intuito de aliviar o "estresse", refletir, aproveitar as condições ambientais favoráveis para a prática de exercícios físicos, para o convívio social entre outras motivações.

Esse último grupo pode ser decomposto por aqueles que frequentam a área de lazer da Floresta da Tijuca entre quatro e dez vezes por ano $(14,47 \%)$ e por aqueles que a frequentam mais de dez vezes por ano (32,02\%) (Figura 7 ). 


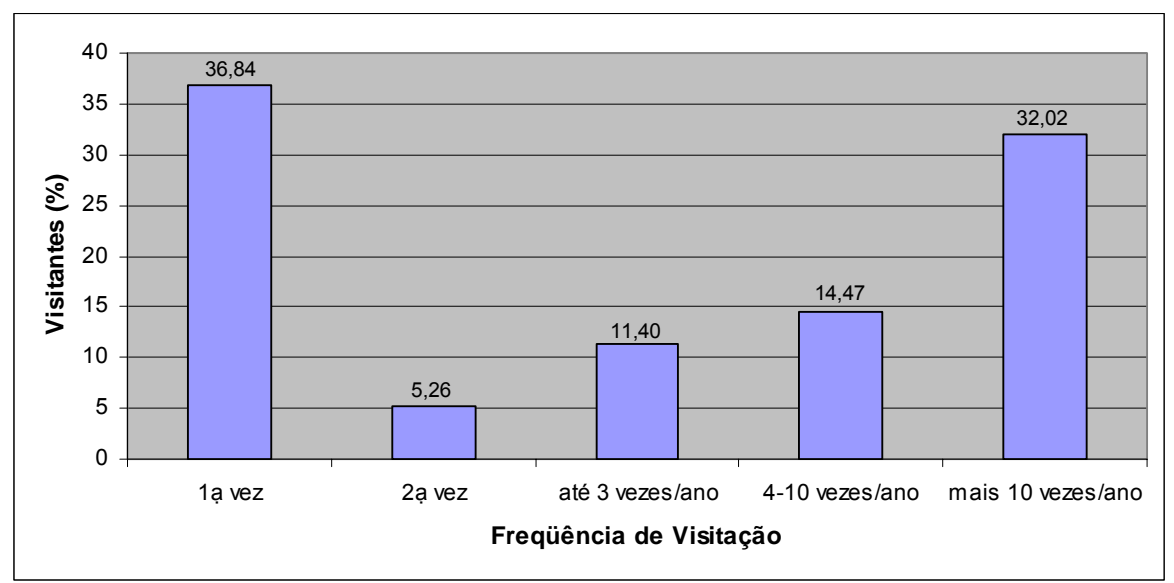

Figura 7 - Frequência de visitação dos entrevistados (\%).

Fonte: pesquisa de campo realizado por Malta (2008).

Dos "frequentadores" da Floresta da Tijuca, 21,95\% visitam-na a menos de cinco anos. Se considerarmos somente os frequentadores há mais de dezesseis anos, chegaríamos a um indicador de 56,10\%.

Isso representa uma área com forte atratividade em termos de lazer para usuários que buscam e valorizam um espaço que tem significado para eles, através de suas memórias, experiências e vivências.

Com relação ao tempo de permanência dos visitantes na Floresta da Tijuca: $51,76 \%$ desenvolvem suas atividades recreativas e ecoturísticas em intervalo de tempo, variando entre duas a quatro horas; $25 \%$ costumam permanecer no parque de quatro a seis horas; e 18,86\% até duas horas (Figura 8).

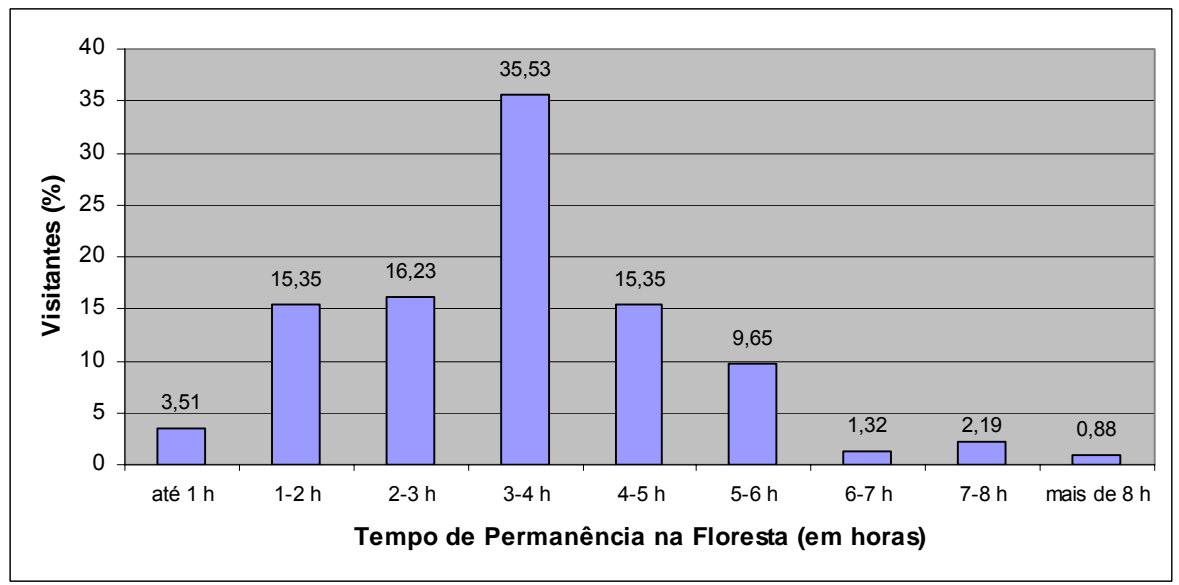

Figura 8 - Tempo de permanência dos visitantes entrevistados na Floresta da Tijuca (\%). Fonte: pesquisa de campo realizado por Malta (2008).

Os principais motivos que levaram os visitantes a procurar a Floresta da Tijuca como área de lazer, recreação e Ecoturismo, foram: o passeio (28,52\%), a contempla- 
Malta, R. R.; Costa, N. M. C.

ção e o contato com a natureza $(18,77 \%)$, e a vontade de "fazer trilhas" $(18,05 \%)$ (Figura 9).

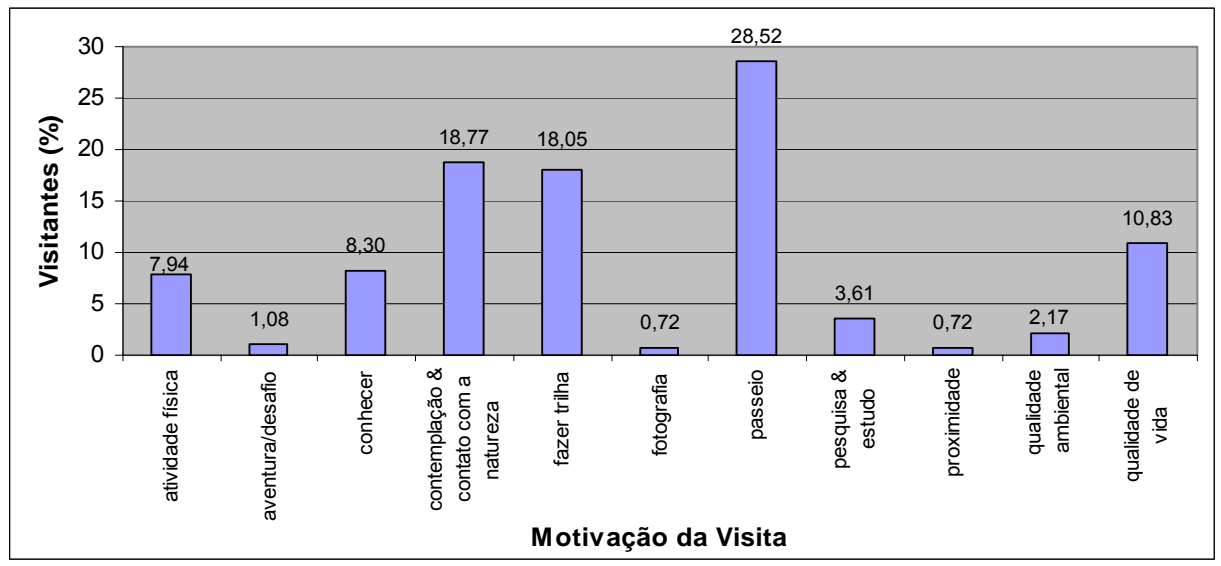

Figura 9 - Motivos que levaram os visitantes à Floresta da Tijuca (\%).

Fonte: pesquisa de campo realizado por Malta (2008).

O principal meio de transporte utilizado para chegar à Floresta da Tijuca é o automóvel $(69,74 \%)$, seguido pelo ônibus (17,11\%). Alguns visitantes utilizaram meios de transporte "combinados" para acessar o parque e voltar para locais de residência.

Questionados sobre as principais atividades realizadas, ou seja, as oportunidades vivenciadas na Floresta da Tijuca, a prática da caminhada foi o item que alcançou as maiores frequências relativas $(45,71 \%)$. Outros itens que merecem menção foram: a observação da paisagem $(12,24 \%)$, a fotografia $(7,76 \%)$, a realização de piqueniques e churrascos $(6,94 \%)$ e a prática de esportes e exercícios físicos $(5,31 \%)$. As respostas (Figura 10) revelaram que o parque oferece uma ampla gama de atividades recreativas e ecoturísticas.

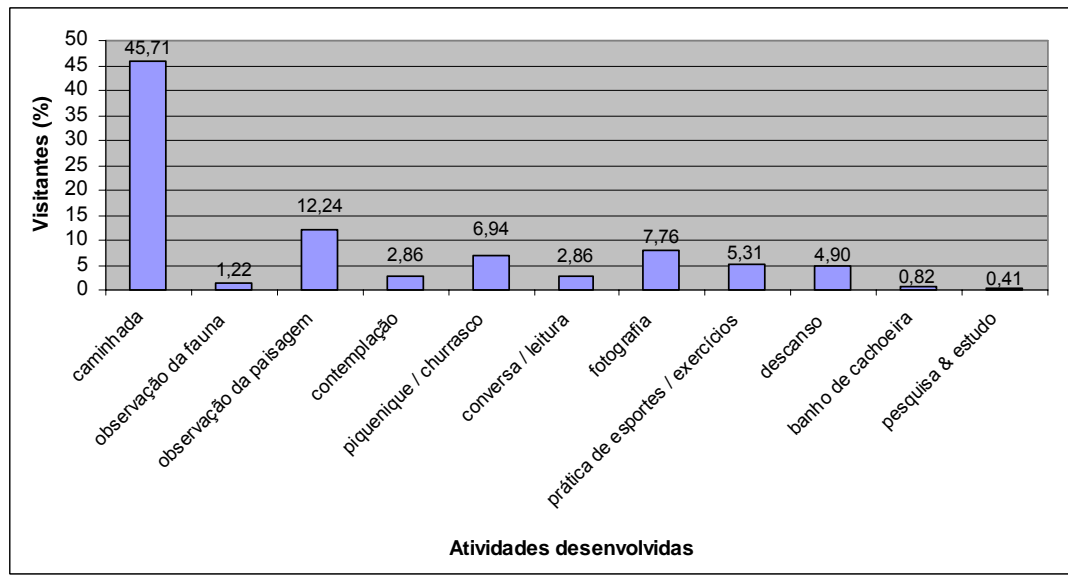

Figura 10 - Atividades desenvolvidas pelos visitantes entrevistados na Floresta da Tijuca (\%). Fonte: pesquisa de campo realizado por Malta (2008). 
O PNT apresenta uma complexa rede de trilhas - em sua maioria sinalizadas , que oferece aos visitantes a oportunidade de desfrutar de mirantes, cachoeiras, grutas, ruínas, entre outros atrativos histórico-culturais e naturais. Por esse motivo, dentre as principais atividades desenvolvidas durante a permanência dos visitantes entrevistados, a caminhada foi o item mais declarado nas respostas.

\section{CONCLUSÕES}

Os apelos ao Ecoturismo e à visitação pública em UC's, como os parques nacionais, têm crescido de forma significativa nos últimos anos. Entretanto, este aumento da demanda por áreas naturais e atividades recreativas, também gerou um aumento na degradação socioambiental - interferências físicas, bióticas e antrópicas (socioeconômicas). Para evitar isso, os gestores dessas áreas devem criar ferramentas capazes de manejar a visitação pública, tais como os Programas de Uso Público que têm por objetivo propiciar lazer, recreação e educação ambiental à comunidade, bem como despertar uma consciência crítica para a necessidade de conservação dos recursos naturais das UC's, além de esclarecer o público, em geral, sobre as responsabilidades, as dimensões e a importância dessas áreas na conservação da biodiversidade.

Para compor um Programa de Uso Público que atenda aos mais variados grupos de pessoas, é imprescindível que o gestor conheça as potencialidades e as limitações de sua unidade e o perfil de seus visitantes. Segundo Kinker (2002), o tipo de visitante que uma área natural protegida recebe e o seu tempo de permanência são determinados pela forma de manejo da visitação que é feita. É ideal que, em um Parque Nacional, se ofereçam opções variadas de atividades para públicos diferenciados.

Nesse sentido, o perfil e as reações dos visitantes da Floresta da Tijuca podem ajudar à administração do PNT a avaliar o atual uso público e promover a criação e/ou melhoria dos atrativos oferecidos, a partir de uma demanda real do visitante em termos de satisfação no desenvolvimento de serviços e atividades recreacionais e ecoturísticas

Entretanto, assim como em outros parques nacionais pesquisados por Kinker (2002), perde-se uma excelente oportunidade de envolver os visitantes com a natureza e com a realidade do PNT. Os visitantes não recebem informações com conteúdo educativo e não são usadas técnicas de interpretação da natureza. Em geral, os visitantes que procuram um Parque Nacional, para práticas de Ecoturismo e lazer na natureza, fazem-no com a expectativa de aprender sobre o meio ambiente visitado, e, para isso, esperam receber informações que enriqueçam sua visita. Os resultados de outra pesquisa realizada por Sant'Anna (2005) na Floresta da Tijuca também apontaram nessa direção. Mesmo aqueles visitantes que já têm algum conhecimento sobre a história do PNT e sua importância para a cidade do Rio de Janeiro, consideram que a administração do parque deveria fornecer mais informações para o visitante.

Tomando como base as sugestões para melhorias e as reclamações dos visitantes entrevistados, algumas recomendações foram indicadas:

- realizar serviços de manutenção nas ciclovias e nas estradas (pavimentadas) 
internas, como também construir ao longo destas, pontos de apoio com instalações básicas, a exemplo de bebedouros e bicicletários - a maioria dos atuais bebedouros encontra-se desativado, e os bicicletários são precários - aparentemente, infraestrutura e serviços, sem manejo ou mal manejados, são inversamente proporcionais à qualidade da experiência do visitante (KINKER, 2002);

- adotar mecanismos que viabilizem a divulgação dos atrativos, funções e serviços oferecidos pelo parque - poderiam ser distribuídos folhetos informativos aos usuários, bem como comercializar souvenires com a imagem do parque, além de veicular a importância socioambiental do PNT através da mídia que se utiliza dos atrativos naturais, histórico-culturais e turísticos em suas programações;

- incrementar ou intensificar ações ligadas à educação e interpretação ambiental com os visitantes e as comunidades vizinhas, com o intuito de esclarecer como melhor utilizar as áreas de lazer do PNT, de ressaltar a importância desses locais, e de conscientizar os atores envolvidos em sua gestão - os visitantes dos três parques nacionais pesquisados por Kinker (2002) também afirmaram que gostariam de receber informações que enriquecessem sua visita;

- maior atuação na fiscalização e na segurança interna do parque, como forma de reduzir as ações que venham a degradar os recursos naturais e a causar prejuízos aos visitantes;

- instalação de uma lanchonete no Centro de Visitantes com preços "mais acessíveis", de forma a atender a demanda do público mais jovem e com menor renda;

- apoiar o serviço de guiamento gratuito realizado pelo Setor de Ecoturismo, pois trata-se um serviço essencial de informação e conscientização ambiental do visitante;

- melhorar as condições de funcionamento dos sanitários públicos, que encontram-se ora fechados, ora em estado precário de uso;

- controlar o acesso demasiado de veículos na PNT nos finais de semana e feriados, pois o excesso de ruído (poluição sonora) prejudica a qualidade da experiência dos visitantes, assim como, primordialmente, a vida silvestre (fauna e a flora);

- incentivar a realização de cursos, eventos e palestras no Centro de Visitantes e divulgá-los para que a sociedade possa participar e se inserir nas discussões e capacitações técnicas, tornando-se sua aliada do parque; e

- valorizar e incentivar o trabalho do voluntariado e do pessoal de campo do PNT, que através de suas práticas de campo realizam melhorias nas trilhas e caminhos, manejam a flora e realizam mutirões mensais de limpeza dos rios, das trilhas e dos atrativos do parque. É, sem dúvida, uma outra forma de inclusão da sociedade no cotidiano do parque, onde o voluntário participa e interage com os funcionários e terceirizados.

Os resultados deste trabalho servem, portanto, para os gestores do PNT buscarem soluções para atender melhor às expectativas desses visitantes, demandadores de qualidade de vida e conservadores de qualidade ambiental, pois buscam não só um contato com a natureza, mas também uma oportunidade de aprender "novos valores" e ter "novas sensibilidades". 
Gestão do Uso Público em Unidade de Conservação: a visitação no Parque Nacional da Tijuca - RJ

\section{REFERÊNCIAS BIBLIOGRÁFICAS}

BANDEIRA, C.M. Parque Nacional da Tijuca. São Paulo: Makron Books, 1993.

BARROS, M.I.A Caracterização da visitação, dos visitantes e avaliação dos impactos ecológicos e recreativos do planalto do Parque Nacional do Itatiaia. 2003. 121 f. Dissertação (Mestrado) - Escola Superior de Agricultura Luiz de Queiroz, Universidade de São Paulo, Piracicaba, 2003.

BARROS, M.I.A; DINES, Milton. Mínimo Impacto em Áreas Naturais: uma mudança de atitude. In: SERRANO, C. (Org.). A educação pelas pedras: Ecoturismo e educação ambiental. São Paulo: Chronos, 2000. p. 47-84.

BRASIL, G. História das ruas do Rio. Rio de Janeiro: Prefeitura do Distrito Federal, Secretaria Geral de Educação e Cultura, 1963.

BRASIL. Lei Federal $\mathbf{n}^{\circ}$ 9.985, de 18 de julho de 2000.

BUENO, C. Conservação de biodiversidade nos parques urbanos: caso do Parque Nacional da Tijuca. 1998. Dissertação (Mestrado) - Universidade Estácio de Sá, Rio de Janeiro, 1998.

CASTRO, R. C. L. A importância do perfil de visitantes para a gestão do uso público em unidades de conservação: um estudo de caso do parque estadual do Ibitipoca-MG. In: Anais do $1^{\circ}$ Encontro de Ecoturismo em Unidades de Conservação - ECOUC. Rio de Janeiro, UERJ/GEA, 2005.

COSTA, V.C. Análise do potencial turístico das regiões administrativas (RAs) de Campo Grande e Guaratiba - RJ. 2002. Dissertação (Mestrado) - Instituto de Geociências, Universidade Federal do Rio de Janeiro, Rio de Janeiro, 2002.

CUNHA E MENEZES, P. Trilhas do Rio. Rio de Janeiro: Salamandra, 1996.

CUNHA E MENEZES, P. Novas Trilhas do Rio. Rio de Janeiro: Editora Sextante, 1998.

DRUMMOND, J.A. Devastação e preservação ambiental: os parques nacionais do estado do Rio de Janeiro. Niterói: EdUFF, 1997.

EUGENE, P. Le tourisme: destructeur ou protecteur de l'environnement? Paris: Espaces, 1980.

FRANCO, M.A.R. Planejamento ambiental para a cidade sustentável. São Paulo: Annablume: FAPESP, 2001. 296 p.

FREITAS, W.K.; MAGALHÃES, L.M.S.; GUAPYASSÚ, M.S. Potencial de uso público do Parque Nacional da Tijuca. Acta Scientiarum, Maringá, v. 24, n. 6, pp. 1833-1842, 2002.

FREIXÊDAS-VIEIRA, V. M.; PASSOLD, A. J.; MAGRO, T. C. Impactos do uso público: um guia de campo para utilização do método VIM. In: CONGRESSO BRASILEIRO DE UNIDADES DE CONSERVAÇÃO. (2:2000: Campo Grande). Anais... Campo Grande: Rede Nacional Pró-unidade de Conservação: Fundação O Boticário de Proteção à Natureza, 2000 3v. p. 296-305. 
IBDF. Plano do Sistema de Unidades de Conservação do Brasil. II Etapa, Brasília, IBDF, 1982.

IBDF/FBCN. Plano de Manejo: Parque Nacional da Tijuca. Brasília, 1981.

IPP - INSTITUTO MUNICIPAL PEREIRA PASSOS. DIRETORIA DE INFORMAÇÕES GEOGRÁFICAS - DIG [On line.]. Mapa de Favelas do município do Rio de Janeiro. 2004. Armazém de Dados - IPP. Rio de Janeiro: Prefeitura Municipal do Rio de Janeiro, Secretaria Municipal de Urbanismo. <http://www.armazemdedados.rio.ri.gov.br>.

IPP - INSTITUTO MUNICIPAL PEREIRA PASSOS. DIRETORIA DE INFORMAÇÕES GEOGRÁFICAS - DIG [On line.]. Divisão de bairros do município do Rio de Janeiro e limites do Parque Nacional da Tijuca. 2005. Armazém de Dados - IPP. Rio de Janeiro: Prefeitura Municipal do Rio de Janeiro, Secretaria Municipal de Urbanismo. <http:// www.armazemdedados.rio.ri.gov.br>.

ISER. Perfil do usuário do Parque Nacional da Tijuca. In: ISER. O Parque Nacional da Tijuca. Contribuição para a gestão compartilhada de uma unidade de conservação urbana. Comunicações do ISER. Rio de Janeiro, n. 54, ano 19, 2000.

ISER/PNT. Proposta de um modelo de gestão participativa para o Parque Nacional da Tijuca. A problemática da ocupação humana no interior e no entorno do Parque Nacional da Tijuca. Consultora: Laila Souza Mendes. Maio 1999.

KINKER, S.M.D. Ecoturismo e conservação da natureza em parques nacionais. 2. ed. Campinas: Papirus, 2002, 224 p. - (Coleção Turismo).

MALTA, R.R. Valoração dos serviços recreativos e ecoturísticos em unidade de conservação: o caso do Parque Nacional da Tijuca, Rio de Janeiro, RJ. 2008. 199 f. Dissertação (Mestrado) - Universidade do Estado do Rio de Janeiro, Instituto de Geografia, Rio de Janeiro, 2008.

MANNELL, R. C.; ISO-AHOLA, S. E. Psychological nature of leisure and tourism experience. Annals of Tourism Research, n. 14, pp. 314-331, 1987.

MATTAR, F. N. Pesquisa de marketing: metodologia, planejamento, execução, análise. 2 v., 2. ed., São Paulo: Atlas, 1994.

MEIRELLES FILHO, J. O equilíbrio entre a atividade econômica e a sustentabilidade. In: MENDONÇA, R.; NEIMAN, Z. (Org.). Ecoturismo no Brasil. Barueri, SP: Manole, 2005.

MMA/IBAMA. Marco conceitual das unidades de conservação federais do Brasil. Brasília: MMA/IBAMA/Direc/GTZ, 1997.

MORLEY, C. L. What is tourism? The Journal of Tourism Studies. n.1, pp. 3-8, 1990.

NIEFER, I.A. Análise do perfil dos visitantes do Parque Nacional do Superagui e da Estação Ecológica llha do Mel. Marketing como instrumento para um turismo sustentável. 2002. 237 f. Tese (Doutorado) - Universidade Federal do Paraná, Curitiba, 2002.

PEARCE, P.L.; MOSCARDO, G. Making sense of tourists' complaints. International Journal of Tourist Management, n. 5, pp. 20-23, 1984. 
PEARCE, P.L.; MOSCARDO, G. Visitor evaluation: an appraisal of goals and tecniques. Evaluation Review, n. 9, pp. 281-306, 1985.

SANT'ANNA, A. B. C. Perfil dos visitantes das trilhas da Floresta da Tijuca (Parque Nacional da Tijuca - RJ). In: Anais do ${ }^{\circ}$ Encontro de Ecoturismo em Unidades de Conservação - ECOUC. Rio de Janeiro, UERJ/GEA, 2005.

SILVA, S.M.S.; REGO, J.F.; PIRES, P.S.; TELLO, J.C.R. Análise do perfil dos visitantes das comunidades de Maguari e Jamaraquá na Floresta Nacional do Tapajós e sua contribuição para a sustentabilidade do Ecoturismo. Anais do $1^{\circ}$ Encontro de Ecoturismo em Unidades de Conservação - ECOUC. Rio de Janeiro, UERJ/GEA, 2005.

TAKAHASHI, L.Y. Caracterização dos visitantes, suas preferências e percepções e avaliação dos impactos da visitação pública em Unidades de Conservação do Estado do Paraná. 1998. Tese (Doutorado). Setor de Ciências Agrárias, Universidade Federal do Paraná, Curitiba, 1998.

TAKAHASHI, L.Y. Uso Público em Unidades de Conservação. Cadernos de Conservação, ano 2, n. 2, Fundação O Boticário de Proteção à Natureza, out. 2004.

\section{Notas}

1 O presente trabalho faz parte da dissertação de mestrado, defendida por Malta (2008), no Programa de Mestrado em Geografia do Instituto de Geografia da UERJ.

${ }^{2}$ O SNUC foi instituído em 18 de julho de 2000, pela Lei $n^{\circ} 9.985$, estabelecendo critérios e normas para a criação, implantação e gestão das Unidades de Conservação (BRASIL, 2000).

${ }^{3}$ Art. $7^{\circ}, \mathrm{II}, \mathrm{d} 1^{\circ}$ da Lei do SNUC.

${ }^{4}$ Conceito utilizado pelo Instituto Municipal de Urbanismo Pereira Passos (IPP)

${ }^{5}$ Nas linguagens dos índios, "tijuca" significa terreno argiloso e lamacento (BRASIL, 1963).

Ricardo Rodrigues Malta: Universidade do Estado do Rio de Janeiro

Email: ricomalta14@ig.com.br

Link para o currículo Lattes: http://lattes.cnpq.br/1285607813813610

Nadja Maria Castilho da Costa: Universidade do Estado do Rio de Janeiro

Email: nadjagea@bol.com.br

Link para o currículo Lattes: http://lattes.cnpq.br/8646672305430213

Data de submissão: 27 de junho de 2009

Data do aceite: 08 de setembro de 2009 